\title{
Editorial: Reductionism and Holism in Behavior Science and Art
}

\author{
Donald A. Hantula ${ }^{1}$ \\ Published online: 13 November 2018 \\ C) Association for Behavior Analysis International 2018
}

How should we handle complexity? In both science and in art, there is tension between the holist view that the properties of any entity or system cannot be understood or explained by its parts alone, and the reductionist view, which holds that an entity or system can be understood or explained by reducing it to its component parts (Graham, 2013). As Kandel (2016) points out, reductionism in science and art serve different, but analogous, purposes. In science, reductionism is used to solve complex problems; in art, reductionism is used to evoke new emotional responses in art consumers. Scientific reductionism is a process of reducing and then rebuilding that often leads to new insights that would not be found in either a solely reductionist or holist view. For example, Kandel began his quest to understand human learning and memory by studying the sea slug (aplysia), and the insights gleaned from intensive study of a simple organism guided and shaped his experimentation leading to brain science (Kandel, 1979). Artistic reductionism also leads to new insights. Through reductionism artists peel away unnecessary details and discover a work's essential features. Consumers of art experience new and often unique affective reactions to art when a visual or musical composition is stripped to its barest parts. ${ }^{1}$ Kandel's book, Reductionism in Art and Brain Science: Bridging the Two Cultures, explores the commonalities between abstract art and brain science, arguing that both pursuits use reductionist methodologies in their search for higher level truths about human nature.

One can adopt holism and accept complexity as an irreducible given, or embrace reductionism and work to disassemble and decompose complexity into simplicity. For

\footnotetext{
${ }^{1}$ For a musical illustration, consider the prevalence of "unplugged" performances and solo acoustic tours by popular music artists who disassemble their electronic and heavily produced songs to its barest skeleton. The emotional reactions evoked by the "unplugged" version are often very different than those evoked by the original version (for example, compare Clapton's electric 1970 version of "Layla" with its 1992 "unplugged" rendition; Clapton \& Gordon, 1970, 1992]).
}

I thank Tom Critchfield, Dave Jarmolowicz, and Erin Rasmussen for their comments on this editorial.

Donald A. Hantula

hantula@temple.edu

1 Temple University, Philadelphia, PA, USA 
example, our world can look like a Florentine Renaissance painting, with all its colors, intricacies, subtleties, shades, and real-life figures that spring from or fade into a murky background. Every little detail is but a small contribution to the whole as seen in the works of artists from that era such as Botticelli (e.g., The Birth of Venus) and Ghirlandaio (e.g., An Old Man and His Grandson). Or our world can also look like an abstract expressionist painting, in which the most basic essential features are represented, and no more, such as Mondrian (e.g., Broadway Boogie-Woogie) or Still (e.g., 1944-N No.1). Or consider two pieces of sculpture: Michelangelo's David and Brancusi's Bird in Space. Michelangelo chiseled marble into the sensuous curves and fine details of the human body. It is complex and realistic. In contrast, Brancusi, also working with marble, created a slim upward thrusting figure that depicts neither birds nor space, but somehow captures the essence of a bird in flight.

These works suggest that in art one is either a reductionist or a holist. In science one can work with both perspectives. Behavior science takes precisely this conciliatory approach. Using the same principles behavior science can explain phenomena at levels ranging from the cellular (Stein, Xue, \& Belluzzi, 1993) to populations (Biglan, 2016) and cultures (Houmanfar \& Mattaini, 2016; Mattaini \& Aspholm, 2016) and everything in between including neuroscience (Ortu \& Vaidya, 2017; Zilio, 2016), developmental systems (Moore, 2016), and economics (Furrebøe \& Sandaker, 2017). It is not necessary to invoke different explanatory principles for different levels of analysis because behavior theory is a scalable system that rests on a fundamental base of selection by consequences (Schneider, 2012), much like Darwinian theory (Donahoe, 2017; Ghiselin, 2018; McDowell, 2017; McDowell \& Klapes, 2018; Popa \& McDowell, 2016; Wasserman, 2012).

Behavior science can also interface with art, bringing new insights to understanding what many regard as the highest achievements of human creativity and imagination. Applications of behavior science to analyzing and understanding art are nearly a century old, such as a "behavioristic" interpretation of jazz, focusing on audience reaction (Eggen, 1926). Behavioral themes and principles are found in interpretations and criticism works of fiction (Brabner, 1979; Dougan, 1987; Newman, 1992; Skinner, 1961), and fiction has been written to explain behavior science to a general audience (Skinner, 1948; SulzerAzaroff, 2010). More recent behavior science scholarship takes a more comprehensive look at art in behavioral perspective, with Mechner's (2018) treatise on a behavioral and biological analysis of aesthetics pushing the boundaries of the art/science divide. Mechner sees "aesthetic" responses as synergistic effects of 16 concept manipulation devices that occur only under conditions of priming. Mechner's article and accompanying commentary (Hineline, 2018; Killeen, 2018; Malott, 2018; Mellon, 2018; Schlinger, 2018; Shimp, 2018; Thompson, 2018; Verhaeghen, 2018) provide a rich source of analytic ideas as well as new directions for research. In turn, aesthetics also informs behavior science research and practice. Behavioral experiments and interventions can be evaluated along aesthetic dimensions (DeLeon, 2011; Hineline, 2005; Pérez-Álvarez \& García-Montes, 2006). This type of aesthetic evaluation may be the essence of social validity.

A reductionist approach to art, such as abstract expressionism, breaks an image down to its essential features: color, line, and form. Behavior science sometimes accomplishes a similar goal by breaking a complex behavior down to its component parts. The reactions to both artistic and behavioral reductionism are often strikingly similar. Noted art critic Kirstein (1948) criticized abstract expressionism for its 
simplicity that removed it from purpose or successful content, artless repetitions, and overreliance on basic forms and color that ignored the complicated and hard learned techniques necessary to create serious art. It is not difficult to find parallel criticisms of behavior science and behavior analysis that note simplicity, replications, reliance on basics (in both theory and visual data analysis), and eschewing needlessly complicated statistical analyses as significant detriments. Like abstract art, behavior science can sometimes bring jarring clarity to an exceedingly complex and confusing issue.

Consider these two examples from the behavior science literature. The first example is escalation of commitment, which is a situation in which there is an initial allocation of resources, some sign of failure, and subsequent increased allocation of resources (Bowen, 1987). Examples of escalation often cited in the literature include the United States's involvement in the Vietnam war, the Taurus IT Project in the UK, and EXPO 86 in British Columbia. These "decision disasters" inspired hundreds of papers describing a complicated jumble of cognitive, motivational, structural, political, organizational, and other determinants (Sleesman, Lennard, McNamara, \& Conlon, 2018). In this view, escalation looks a lot like a High Renaissance painting. Conversely, behavior science research has shown that the causes of escalation can be reduced to basic behavioral principles, which may bring new clarity to the situation. Escalation can result from intermittent reinforcement (Brecher \& Hantula, 2005; Goltz, 1992; Hantula \& Crowell, 1994), momentum (Goltz, 1999), and uncertainty as a motivating operation for information search (Bragger, Bragger, Hantula, \& Kirnan, 1998; Bragger, Hantula, Bragger, Kirnan, \& Kutcher, 2003); can be facilitated via stimulus control (i.e., the "sunk cost effect"; Sofis, Jarmolowicz, Hudnall, \& Reed, 2015); and it can be modeled as a Bayesian process (Gilroy \& Hantula, 2016). Simple, yet effective. And clear.

The second example is delay discounting. On the surface it may seem absurd that a task that was derived from an experiment with pigeons (Ainslie \& Herrnstein, 1981), and then extrapolated to humans, one that involves asking a series of questions about preferring $\$ 10$ today to some other amount in the future, may have anything to do with anything. But it turns out that discounting curves and the $k$ and AUC parameters that describe them have much to do with everything, from a takedown of rational choice theory (Herrnstein, 1990), to maternal health (Higgins et al., 2017; Yoon et al., 2007), genetic sensitization to alcohol (Mitchell, Reeves, Li, \& Phillips, 2006), classroom token economies (Reed \& Martens, 2011), obesity (Jarmolowicz et al., 2017; Lawyer, Boomhower, \& Rasmussen, 2015), melanoma detection (Critchfield \& Howard, 2016), and predicting substance abuse treatment outcomes (Stanger et al., 2012) These connections are so diverse that delay discounting is considered a trans-disease process that may underlie many health-related outcomes (Bickel, Jarmolowicz, Mueller, Koffarnus, \& Gatchalian, 2012). Not bad for a pretty hyperbolic curve. Of course, a behavior science view of escalation or delay discounting cannot capture everything, and what about-ism will always abound, but like an abstract expressionist painting, the essential features are depicted and the superfluous details do not add, but rather subtract from its elegance and power.

\section{In This Issue}

The present issue of Perspectives on Behavior Science runs the full range from reductionism to holism in behavior science. If brain science seems too reductionistic, 
the present issue pushes the matter further with a series of articles on brain-less learning. It then soars to a 30,000-foot view with a target article and commentaries on narrative. Other articles in this issue extend the holistic perspective by taking on scientific translation, flirtation, maternal health, and free will. Despite the complexity and social importance of the problems these articles take on, the simple sophistication, grace, and power of a behavioral analysis shines through each article, much like the heavenly bodies in Van Gogh's Starry Night.

\section{Special Sections}

\section{Brains Optional}

It may seem axiomatic that a brain is necessary for learning. The brain is where the action is and where "learning" takes place, from the Scarecrow in The Wizard of Oz to contemporary neuroscience research. Or is it? Erin Rasmussen assembled and edited a special section titled Learning: No Brains Required. This collection of conceptual and review articles raises serious and provocative questions about the role and necessity for a brain and nervous system in learning, and explores learning in such "simple" creatures as crayfish, planaria, and even plants. The potential to advance theory and research is clear.

However, this special section also has important implications for education, and may even herald a return of operant laboratories in the undergraduate curriculum. If these simple organisms engage in basic respondent and operant behavior, then they may help revive "live labs," as the cost and administration of such an instructional lab is much less than one using avian or mammal species. Is such a lab feasible? Deochand et al.'s article and accompanying video in the special section on employing planaria in behavioral research, and a recent article describing operant research with Madagascar Hissing Cockroaches (Dixon, Daar, Gunnarsson, Johnson, \& Shayter, 2016), suggest an affirmative.

\section{Tell Me a Story}

Also in this issue is a section on the analysis of narrative, the social process of telling stories to entertain, inform, and persuade. The section, coedited by Tom Critchfield and L. Kimberly Epting, features a target article by Philip Hineline plus expert commentary. At the most general level, Hineline's article is noteworthy for addressing that no-(wo)man's land of contemporary behavior analysis, molar relations in the freeflowing verbal behavior of sophisticated speakers and listeners (typically our field has addressed fairly discrete verbal abilities in persons with disabilities). At a specific level, Hineline discusses the importance of "storytelling" in human verbal interactions and the special capacity of stories to sustain attention and motivate action. Building on prior work (Barnes-Holmes \& Barnes-Holmes, 2002; Grant, 2005), he proposes a rubric for analyzing the features of effective stories, and discusses the potential for using storytelling to promote our field to the general public. The commentaries were invited, not to critique Hineline's article per se, but rather to explore and expand upon a broad range of issues suggested by it. 


\section{Regularly Scheduled Papers}

Basic research abstracts essential principles of nature. Translating these findings into pragmatic and useful research and effective action is a challenge that bedevils all sciences. Advocating a move beyond "bench to bedside" and "translational research" models found in the medical literature, Elizabeth Kyonka and Shrinidhi Subramaniam present an organizing scheme for behavioral research as a tiered spectrum. The traditional translational medical models that they abjure have yielded a median translation lag of 24 years (Contopoulos-Ioannidis, Alexiou, Gouvias, \& Ioannidis, 2008); a more nuanced and behaviorally oriented translational model may well yield more rapid adoption. Flirtation is complex verbal behavior that is socially significant, biologically important, and largely undefined. Jennifer Wade provides a behavioral analysis of flirtation based on both rule-governed and contingency-shaped behavior, revealing that Cyrano de Bergerac's secret may have been the autoclitic. Yukiko Washio and Mara Humphreys outline an agenda for behavioral research in health with pregnant and postpartum women. Although incentive-based interventions have proven successful with this population (Washio et al., 2017), its vulnerability raises questions about the ethics and social validity on incentives and other behavior change strategies that are addressed in the article. Finally, Michael Clayton revisits the free will versus determinism argument with a review of Harris's book Free Will.

\section{Giving Thanks}

The eminent philosopher Alfred North Whitehead observed that no one who achieves success does so without acknowledging the help of others. By all measures, PoBS is a successful journal. We have a global reach, and according to data from Springer, we handled over 100 submissions in 2017, and 2018 is on track for the same. Over 47,000 PoBS articles were downloaded from the Springer website in 2017 and the 2017 PoBS Impact Factor is 1.357. PoBS authors have crafted excellent papers and are duly recognized for achievements. However, there are many other people whose work behind the scenes has been invaluable in the journal's rise; those are the members of the $P o B S$ editorial board.

Editorial board members labor in the background as silent collaborators with authors. PoBS editorial board members have been exemplary in providing timely, indepth, and helpful reviews. Our editorial board members make good papers better and provide much constructive feedback to authors of papers that we cannot accept. Through their efforts $P o B S$ now publishes many more articles than ever before and boasts a 30-day mean time to initial decision. But beyond these contributions, the PoBS editorial board continues to be an excellent source of ideas, guidance, and counsel as we have made the transition into a wide-ranging journal of behavior science. I thank outgoing editorial board members Keith Allen, Cindy Anderson, Yvonne BarnesHolmes, Robyn Catagnus, Simon Dymond, Daniel Fienup, Shawn Gilroy, Randy Grace, Alan Gross, Brian Kangas, Sean Laraway, and Chris Newland for their hard work, expert reviews, and sage advice over the past two years. They have served the journal and the discipline with great distinction. 


\section{Going Fourward}

PoBS will double its output and become a quarterly journal in 2019. This development has some important implications for readers and authors. For PoBS readers, the journal will appear in your postal mail four times each year, making articles more immediately accessible and timely. For authors, we will continue the PoBS "special plus" format (Hantula, 2018) in which issues will be built around a special section, theme, or paper and articles. Articles and commentaries that are submitted for a particular "special plus" issue and are accepted for that issue will be accepted contingent upon it being finalized by the production deadline. All matters must be completed (all revisions, preproduction changes, author queries) by the production deadline for that issue; if they are not completed the paper will be rejected.

\section{In Memoriam}

As this issue was going to press we received the sad news that John A. ("Tony") Nevin passed away. Dr. Nevin made many major contributions to behavior science theory and its application. The next issue of $P o B S$ will feature a memoriam piece celebrating Professor Nevin's life and achievements.

Publisher's Note Springer Nature remains neutral with regard to jurisdictional claims in published maps and institutional affiliations.

\section{References}

Ainslie, G., \& Herrnstein, R. J. (1981). Preference reversal and delayed reinforcement. Animal Learning \& Behavior, 9(4), 476-482. https://doi.org/10.3758/BF03209777.

Barnes-Holmes, Y., \& Barnes-Holmes, D. (2002). Naming, story telling, and problem solving: Critical elements in the development of language and cognition. Behavioral Development Bulletin, 11(1), 34-38.

Bickel, W. K., Jarmolowicz, D. P., Mueller, E. T., Koffarnus, M. N., \& Gatchalian, K. M. (2012). Excessive discounting of delayed reinforcers as a trans-disease process contributing to addiction and other diseaserelated vulnerabilities: Emerging evidence. Pharmacology \& Therapeutics, 134, 287-297.

Biglan, A. (2016). The need for a more effective science of cultural practices. The Behavior Analyst, 39(1), 97-107. https://doi.org/10.1007/s40614-016-0051-z.

Bowen, M. G. (1987). The escalation phenomenon reconsidered: Decision dilemmas or decision errors? Academy of Management Review, 12(1), 52-66. https://doi.org/10.2307/257993.

Brabner, G. (1979). A link between the arts and the sciences? B. F. Skinner's concept of contingencies of reinforcement. The Psychological Record, 29(1), 57-64.

Bragger, J. D., Bragger, D., Hantula, D. A., \& Kirnan, J. (1998). Hysteresis and uncertainty: The effect of uncertainty on delays to exit decisions. Organizational Behavior \& Human Decision Processes, 74(3), 229-253. https://doi.org/10.1006/obhd.1998.2779.

Bragger, J. D., Hantula, D. A., Bragger, D., Kirnan, J., \& Kutcher, E. (2003). When success breeds failure: History, hysteresis, and delayed exit decisions. Journal of Applied Psychology, 88(1), 6-14. https://doi. org/10.1037/0021-9010.88.1.6.

Brecher, E. G., \& Hantula, D. A. (2005). Equivocality and escalation: A replication and preliminary examination of frustration. Journal of Applied Social Psychology, 35(12), 2606-2619. https://doi. org/10.1111/j.1559-1816.2005.tb02116.x. 
Clapton, E., \& Gordon, J. (1970, November). "Layla" [Recorded by E. Clapton]. On Layla and other assorted love songs. Miami, FL: Tom Dowd.

Clapton, E., \& Gordon, J. (1992, January). "Layla" [Recorded by E. Clapton]. On Unplugged [CD]. Berkshire, MA: Russ Titelman.

Contopoulos-Ioannidis, D. G., Alexiou, G. A., Gouvias, T. C., \& Ioannidis, J. P. A. (2008). Life cycle of translational research for medical interventions. Science, 321(5894), 1298-1299.

Critchfield, T. S., \& Howard, N. L. (2016). Modeling the detection of early-evolving melanoma symptoms: Role of cancer information and delay discounting. The Psychological Record, 66(4), 503-514. https://doi. org/10.1007/s40732-016-0190-3.

DeLeon, I. G. (2011). The aesthetics of intervention in defense of the esoteric. The Behavior Analyst, 34(1), 41-45. https://doi.org/10.1007/BF03392233.

Dixon, M. R., Daar, J. H., Gunnarsson, K., Johnson, M. L., \& Shayter, A. M. (2016). Stimulus preference and reinforcement effects of the Madagascar hissing cockroach (Gromphordahina portentosa): A case of reverse translational research. The Psychological Record, 66(1), 41-51. https://doi.org/10.1007/s40732015-0149-9.

Donahoe, J. W. (2017). Behavior analysis and neuroscience: Complementary disciplines. Journal of the Experimental Analysis of Behavior, 107(3), 301-320. https://doi.org/10.1002/jeab.251.

Dougan, J. D. (1987). Reinforcement in the sixteenth century: Was the Bard a behaviorist? The Behavior Analyst, 10(2), 189-196. https://doi.org/10.1007/BF03392429.

Eggen, J. B. (1926). A behavioristic interpretation of jazz. Psychological Review, 33(5), 407-409. https://doi. org/10.1037/h0071726.

Furrebøe, E. F., \& Sandaker, I. (2017). Contributions of behavior analysis to behavioral economics. The Behavior Analyst, 40(2), 315-327. https://doi.org/10.1007/s40614-017-0110-0.

Ghiselin, M. T. (2018). B. F. Skinner and the metaphysics of Darwinism. Perspectives on Behavior Science, 41(1), 269-281. https://doi.org/10.1007/s40614-018-0139-8.

Gilroy, S. P., \& Hantula, D. A. (2016). Inherently irrational? A computational model of escalation of commitment as bayesian updating. Behavioural Processes, 127, 43-51. https://doi.org/10.1016/j. beproc.2016.02.017.

Goltz, S. M. (1992). A sequential learning analysis of decisions in organizations to escalate investments despite continuing costs or losses. Journal of Applied Behavior Analysis, 25(3), 561-574. https://doi. org/10.1901/jaba.1992.25-561.

Goltz, S. M. (1999). Can't stop on a dime: The roles of matching and momentum in persistence of commitment. Journal of Organizational Behavior Management, 19(1), 37-63. https://doi.org/10.1300 $/ J 075 \mathrm{v} 19 \mathrm{n} 0105$.

Graham, D. J. (2013). Integrating holism and reductionism in the science of art perception. Behavioral and Brain Sciences, 36(2), 145-146. https://doi.org/10.1017/s0140525x12001653.

Grant, L. K. (2005). The secrets of Scheherazade: Toward a functional analysis of imaginative literature. Analysis of Verbal Behavior, 21, 181-190. https://doi.org/10.1007/bf03393020.

Hantula, D. A. (2018). Behavior science emerges. Perspectives on Behavior Science, 41(1), 1-6. https://doi. org/10.1007/s40614-018-0163-8.

Hantula, D. A., \& Crowell, C. R. (1994). Intermittent reinforcement and escalation processes in sequential decision making: A replication and theoretical analysis. Journal of Organizational Behavior Management, 14(2), 7-36. https://doi.org/10.1300/J075v14n02_03.

Herrnstein, R. J. (1990). Rational choice theory: Necessary but not sufficient. American Psychologist, 45(3), 356-367. https://doi.org/10.1037/0003-066X.45.3.356.

Higgins, S. T., Reed, D. D., Redner, R., Skelly, J. M., Zvorsky, I. A., \& Kurti, A. N. (2017). Simulating demand for cigarettes among pregnant women: A low-risk method for studying vulnerable populations. Journal of the Experimental Analysis of Behavior, 107(1), 176-190. https://doi.org/10.1002/jeab.232.

Hineline, P. N. (2005). The aesthetics of behavioral arrangements. The Behavior Analyst, 28(1), 15-28. https://doi.org/10.1007/BF03392101.

Hineline, P. N. (2018). Challenge of the ineffable: Concerning Mechner's "A behavioral and biological analysis of aesthetics". The Psychological Record, 68(3), 323-324. https://doi.org/10.1007/s40732-0180309 .

Houmanfar, R. A., \& Mattaini, M. A. (2016). Leadership and cultural change: Implications for behavior analysis. The Behavior Analyst, 39(1), 41-46. https://doi.org/10.1007/s40614-016-0064-7.

Jarmolowicz, D. P., Hudnall, J. L., Hale, L., Fowler, S. C., Bortolato, M., Lemley, S. M., \& Sofis, M. J. (2017). Delay discounting as impaired valuation: Delayed rewards in an animal obesity model. Journal of the Experimental Analysis of Behavior, 108(2), 171-183. https://doi.org/10.1002/jeab.275. 
Kandel, E. R. (1979). Behavioral biology of aplysia: A contribution to the comparative study of opisthobranch molluscs. New York, NY: Freeman.

Kandel, E. R. (2016). Reductionism in art and brain science: Bridging the two cultures. New York, NY: Columbia University Press.

Killeen, P. R. (2018). A ludic appreciation of mechner's aesthetics. The Psychological Record, 68(3), 325330. https://doi.org/10.1007/s40732-018-0317-9.

Kirstein, L. (1948). The state of modern painting. Harper's Magazine, 197(1181), 47-53.

Lawyer, S. R., Boomhower, S. R., \& Rasmussen, E. B. (2015). Differential associations between obesity and behavioral measures of impulsivity. Appetite, 95, 375-382. https://doi.org/10.1016/j.appet.2015.07.031.

Malott, M. E. (2018). What influences audience response to figure painting? The Psychological Record, 68(3), 331-341. https://doi.org/10.1007/s40732-018-0313-0.

Mattaini, M. A., \& Aspholm, R. (2016). Contributions of behavioral systems science to leadership for a new progressive movement. The Behavior Analyst, 39(1), 109-121. https://doi.org/10.1007/s40614-015-0043-4.

McDowell, J. J. (2017). The effect of reinforcement, and the roles of mutation rate and selection pressure, in an evolutionary theory of behavior dynamics. The Behavior Analyst, 40(1), 75-82. https://doi.org/10.1007 /s40614-017-0094-9.

McDowell, J. J., \& Klapes, B. (2018). An evolutionary theory of behavior dynamics applied to concurrent ratio schedules. Journal of the Experimental Analysis of Behavior. https://doi.org/10.1002/jeab.468.

Mechner, F. (2018). A behavioral and biological analysis of aesthetics: Implications for research and applications. The Psychological Record, 68(3), 287-321. https://doi.org/10.1007/s40732-017-0228-1.

Mellon, R. C. (2018). A Technology of Aesthetic Appreciation: Tweaking the Reinforcing Potency of Synergetic Events. The Psychological Record, 68(3), 343-346. https://doi.org/10.1007/s40732-0180316-X.

Mitchell, S. H., Reeves, J. M., Li, N., \& Phillips, T. J. (2006). Delay discounting predicts behavioral sensitization to ethanol in outbred WSC mice. Alcoholism: Clinical \& Experimental Research, 30(3), 429-437. https://doi.org/10.1111/j.1530-0277.2006.00047.x.

Moore, D. S. (2016). The developmental systems approach and the analysis of behavior. The Behavior Analyst, 39(2), 243-258. https://doi.org/10.1007/s40614-016-0068-3.

Newman, B. (1992). Brave New World Revisited revisited: Huxley's evolving view of behaviorism. The Behavior Analyst, 15(1), 61-69. https://doi.org/10.1007/BF03392586.

Ortu, D., \& Vaidya, M. (2017). The challenges of integrating behavioral and neural data: Bridging and breaking boundaries across levels of analysis. The Behavior Analyst, 40(1), 209-224. https://doi. org/10.1007/s40614-016-0074-5.

Pérez-Álvarez, M., \& García-Montes, J. M. (2006). Person, behaviour, and contingencies (an aesthetic view of behaviourism). International Journal of Psychology, 41(6), 449-461. https://doi.org/10.1080 /00207590500491585.

Popa, A., \& McDowell, J. J. (2016). Behavioral variability in an evolutionary theory of behavior dynamics. Journal of the Experimental Analysis of Behavior, 105(2), 270-290. https://doi.org/10.1002/jeab.199.

Reed, D. D., \& Martens, B. K. (2011). Temporal discounting predicts student responsiveness to exchange delays in a classroom token system. Journal of Applied Behavior Analysis, 44(1), 1-18. https://doi. org/10.1901/jaba.2011.44-1.

Schlinger, H. D. (2018). A functional analysis of "aesthetic": A commentary on mechner. The Psychological Record, 68(3), 353-358. https://doi.org/10.1007/s40732-018-0308-x.

Schneider, S M. (2012). The science of consequences: How they affect genes, change the brain, and impact our world. Amherst, NY: Prometheus Books.

Shimp, C. P. (2018). Science shapes the beautiful: Shaping moment-to-moment aesthetic behavior. The Psychological Record, 68(3), 359-364. https://doi.org/10.1007/s40732-018-0311-2.

Skinner, B. F. (1948). Walden two. Oxford, UK: Macmillan.

Skinner, B. F. (1961). Has Gertrude Stein a secret? In B. F. Skinner (Ed.), Cumulative record (Enlarged ed.).(pp. 261-271). East Norwalk, CT: Appleton-Century-Crofts.

Skinner, B. F. (1972). A lecture on "having" a poem. In B. F. Skinner (Ed.), Cumulative record (3rd ed., pp. 345-355). New York, NY: Appleton-Century-Crofts.

Sleesman, D. J., Lennard, A. C., McNamara, G., \& Conlon, D. E. (2018). Putting escalation of commitment in context: A multilevel review and analysis. Academy of Management Annals, 12(1), 178-207. https://doi. org/10.5465/annals.2016.0046.

Sofis, M. J., Jarmolowicz, D. P., Hudnall, J. L., \& Reed, D. E. (2015). On sunk costs and escalation. The Psychological Record, 65, 487-494. https://doi.org/10.1007/s40732-015-0124-5. 
Stanger, C., Ryan, S. R., Fu, H., Landes, R. D., Jones, B. A., Bickel, W. K., \& Budney, A. J. (2012). Delay discounting predicts adolescent substance abuse treatment outcome. Experimental \& Clinical Psychopharmacology, 20(3), 205-212. https://doi.org/10.1037/a0026543.

Stein, L., Xue, B. G., \& Belluzzi, J. D. (1993). A cellular analogue of operant conditioning. Journal of the Experimental Analysis of Behavior, 60(1), 41-53. https://doi.org/10.1901/jeab.1993.60-41.

Sulzer-Azaroff, B. (2010). Who killed my daddy? A behavioral safety fable. Cambridge, MA: Cambridge Center for Behavioral Studies.

Thompson, T. (2018). Behavioral functions of aesthetics: Science and art, reason, and emotion. The Psychological Record, 68(3), 365-377. https://doi.org/10.1007/s40732-018-0314-z.

Verhaeghen, P. (2018). Once more, with feeling: The role of familiarity in the aesthetic response. The Psychological Record, 68(3), 379-384. https://doi.org/10.1007/s40732-018-0312-1.

Washio, Y., Humphreys, M., Colchado, E., Sierra-Ortiz, M., Zhang, Z., Collins, B. N., . . Kirby, K. C. (2017). Incentive-based intervention to maintain breastfeeding among low-income Puerto Rican mothers. Pediatrics, 139(3), 1-9.

Wasserman, E. A. (2012). Species, tepees, Scotties, and jockeys: Selected by consequences. Journal of the Experimental Analysis of Behavior, 98(2), 213-226. https://doi.org/10.1901/jeab.2012.98-213.

Yoon, J. H., Higgins, S. T., Heil, S. H., Sugarbaker, R. J., Thomas, C. S., \& Badger, G. J. (2007). Delay discounting predicts postpartum relapse to cigarette smoking among pregnant women. Experimental \& Clinical Psychopharmacology, 15(2), 176-186. https://doi.org/10.1037/1064-1297.15.2.186.

Zilio, D. (2016). Who, what, and when: Skinner's critiques of neuroscience and his main targets. The Behavior Analyst, 39(2), 197-218. https://doi.org/10.1007/s40614-016-0053-x. 